\title{
Two-Year Results of Community-Based Screening Program for Human Papilloma Virus DNA in Çorum Province
}

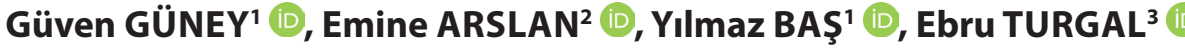 \\ Department of ${ }^{1}$ Pathology, ${ }^{2}$ Obstetric and Gynecology, and ${ }^{3}$ Biostatistics, Hitit University, Faculty of Medicine, ÇORUM, TURKEY
}

\begin{abstract}
Objective: The Turkish Ministry of Health started a community-based screening program using Human Papilloma Virus (HPV) DNA in 2014. In our study, we aimed to investigate the results of this survey in Çorum province between the years of 2016-17 to determine the shortcomings and deficiencies in practice.

Material and Method: All of the women between the ages of 30 and 65 years who had undergone High risk HPV DNA screening in Çorum province between 2016 and 2017 were included in the study. High risk HPV types were divided into three categories as type 16, 18 and others. The target group of patients to be screened were compared with the numbers reached in the survey. After colposcopic biopsy, the clinicopathological correlation of the patients who underwent colposcopic biopsy was determined via pathology reports.

Results: HPV DNA was detected in 817 women (3.5\%). HPV types 16, 18 and others were found to be positive in 216, 32 and 569 individuals, respectively. Cervical biopsy was performed with colposcopy in $212(26 \%)$ women. As the result of colposcopy, LSIL and HSIL were detected in 63 and 56 patients, respectively. 34.5\% of patients with the diagnosis of any kind of dysplasia received treatments.

Conclusion: It was determined that $44 \%$ of HPV DNA-positive patients were not subjected to the appropriate processes according to the national guidelines. This shows that despite the screening, the desired therapeutic effect could not be achieved.
\end{abstract}

Key Words: Uterine cervical neoplasm, HPV DNA test, Turkey, Diagnostic Screening Programs

\section{INTRODUCTION}

Cervical cancer is the third most common cancer in women all over the world, leading to considerable morbidity and mortality (1). A number of epidemiological and molecular studies have shown that Human Papilloma Virus (HPV) is the main cause of cervical cancer and more than $90 \%$ of all cervical cancers are positive for HPV DNA (2-5).

Invasive carcinogenesis of HPV is found to be related to precancerous lesions and this process takes a long time (6). Therefore, necessary precautions can be taken before invasive cancer develops by means of HPV screening programs. It has also been possible to provide prophylaxis with improved HPV vaccines against this virus since 2006 $(7,8)$. The effective use of HPV screening programs in developed countries has led to a decline in the incidence of cervical cancer when compared to developing countries (9).

The Turkish Ministry of Health launched a communitybased screening program using cervical smears in 2004 (1015). However, the result was far below expectation, and only $1-2 \%$ of the targeted population could be detected (14). As

(Turk Patoloji Derg 2019, 35:102-106)

Received : 18.09.2018 Accepted : 27.01.2019 a result, a new strategy was set in 2014 and a communitybased screening program using HPV DNA was introduced.

In our study, we aimed to present the results of this survey in Çorum province between the years of 2016-2017 to determine the shortcomings and deficiencies in the practice.

\section{MATERIAL and METHODS}

All of the women between the ages of 30 and 65 years who had undergone high risk HPV DNA screening in Çorum province within the scope of the National Screening Program by the Çorum provincial health directorate between the years of 2016 and 2017 were included in the study. Within the scope of the screening, two samples were taken from each woman by the family physicians. The first sample was collected with a brush and transferred to a glass slide for conventional cytology. The second was taken with a different brush and put into $5 \mathrm{ml}$ of Standard Transport Medium for HPV DNA analysis. For women who were HPV positive by Hybrid Capture 2 (Qiagen), genotyping was performed with the CLART kit (Genomica).

The high risk HPV types detected in these patients and the ages of the patients were obtained from the relevant

Correspondence: Güven GÜNEY

Hitit University, Faculty of Medicine,

Department of Pathology, ÇORUM, TURKEY

E-mail: dr.guvenguney61@gmail.com Phone: +90 5539790772 
department in the Health Directorate by official application. High risk HPV types were divided into three categories as type 16, 18 and others (type $31,33,34,35,39,45,51,52,56,58,5$ $9,66,68$ and 70). If more than one type of HPV was detected in a patient and one of them was HPV type 16 or 18 , this case was evaluated as HPV type 16 or 18.

The HPV DNA positive patients who were referred to the Hitit University Erol Olcok Education and Research Hospital, the only hospital where colposcopy can be performed in Çorum, and who were examined by colposcopy were determined via the hospital automation system. The clinicopathological correlation of the patients who underwent colposcopic biopsy was determined via pathology reports. The pathology results of the colposcopic biopsy materials were classified as Normal / Low grade squamous intraepithelial lesion (LSIL) and high grade squamous intraepithelial lesion (HSIL). Patients who underwent conization/loop electro surgical excision (LEEP)/ hysterectomy after colposcopic biopsy were again determined through the system and the results of the procedures were determined from the pathology reports.

The target group of patients to be screened were divided into age ranges according to Turkish Statistical Institute (TSI) data and the number of women in each age range was determined. Within the national cancer screening program, this population was planned to be screened in 5 years. So, the number of people to be screened for 2 years covering the years of 2016-2017 was determined as the target population to be reached and compared with the numbers reached in the survey.

\section{RESULTS}

Within the scope of the national cancer screening program, HPV DNA screening was performed in a total of 23,010 women in Çorum province, 12,144 in 2016 and 10,866 in 2017 (Figure 1). Based on TSI data, the targeted number for the two years of the screening program was 47,557 . The total number of the women reached at the end of two years screening program was 23,010 , which corresponds to $48.3 \%$ of the targeted number. The number of the patients reached in the screening program closest to the target number of patients was in 50-59 years group (59\%). However, the lowest number of patients reached compared to the number of targeted patients was in the 30-39 years group (38\%) (Figure 1).

As a result of screening, HPV DNA was detected in 817 women. This number corresponds to $3.5 \%$ of the entire female population screened. When distributed according to HPV types; HPV types 16, 18 and others were found to be positive in $216(0.9 \%), 32(0.1 \%)$ and $569(2.5 \%)$ individuals, respectively. The ratios of the entire screening population were evaluated: HPV positivity rate was highest in 30-39 years group (\%4.2) and lowest in 60-65 years group (\% 2.9) (Table I).

Table I: Distribution of HPV types and percentages of positivity according to age.

\begin{tabular}{lccccc}
\hline & $\mathbf{3 0 - 3 9}$ years & $\mathbf{4 0 - 4 9}$ years & $\mathbf{5 0 - 5 9}$ years & $\mathbf{6 0 - 6 5}$ years & Total \\
\hline HPV type 16 & $72(1.2 \%)$ & $58(0.8 \%)$ & $61(0.79 \%)$ & $25(0.9 \%)$ & 216 \\
\hline HPV type 18 & $11(0.19 \%)$ & $11(0.16 \%)$ & $7(0.09 \%)$ & $3(0.1 \%)$ & 32 \\
\hline HPV other types & $160(2.8 \%)$ & $188(2.7 \%)$ & $168(2.1 \%)$ & $53(1.9 \%)$ & 569 \\
\hline Total & $243(4.2 \%)$ & $257(3.7 \%)$ & $236(3.7 \%)$ & $81(2.9 \%)$ & 817 \\
\hline
\end{tabular}

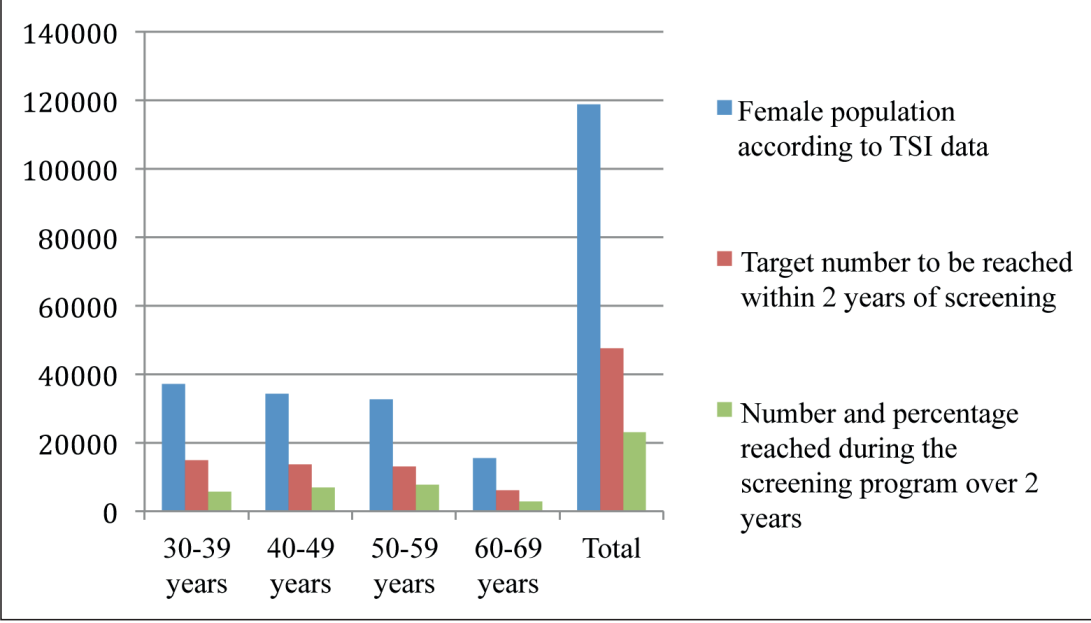

Vol. 35, No. 2, 2019; Page 102-106 
Two hundred and twelve out of 817 (26\%) women with HPV DNA positivity underwent colposcopic biopsy. When this number was distributed according to HPV types, colposcopic biopsy was performed for patients with HPV types 16, 18 and others at a rate of 126/216 (58\%), $13 / 32(40 \%)$ and $73 / 569$ (13\%), respectively. According to the algorithm determined by the national guidelines, colposcopic biopsy should have been performed for HPV type 16 and 18 positive cases. Colposcopy was performed for $56 \%$ of the women in this group (139/248) (Table II).

When the results of colposcopic biopsies were evaluated, 63 patients (30\%) had LSIL, 56 patients had HSIL and 93 patients (44\%) had no dysplasia. When this evaluation was performed according to HPV types, LSIL was detected in 32 (28\%), 3 (24\%) and 20 (28\%) cases for type 16, 18 and other types of HPV, respectively. HSIL was found in 39 (31\%), $6(46 \%)$ and $11(15 \%)$ cases for type 16,18 and other types of HPV respectively. The dysplasia (LSIL + HSIL) detection rate was 79 (62.6\%), 9 (69.2\%) and 31 (42\%) cases in HPV type 16,18 and other types of HPV groups, respectively (Table II).

Ten of 63 patients with LSIL (\%16), 31 of 56 patients with HSIL (55\%), and a total of 41 of 119 patients with the diagnosis of any kind of dysplasia (34.5\%) underwent

Table II: Colposcopy results according to HPV types.

\begin{tabular}{lccc}
\hline & Non SIL & LSIL & HSIL \\
\hline $\begin{array}{l}\text { HPV type 16 } \\
\mathbf{n}=\mathbf{1 2 6}(\mathbf{1 0 0 \% )}\end{array}$ & $47(37 \%)$ & $40(32 \%)$ & $39(31 \%)$ \\
\hline $\begin{array}{l}\text { HPV type 18 } \\
\mathbf{n}=\mathbf{1 3}(\mathbf{1 0 0 \% )}\end{array}$ & $4(30 \%)$ & $3(24 \%)$ & $6(46 \%)$ \\
\hline $\begin{array}{l}\text { HPV other } \\
\mathbf{n}=\mathbf{7 3}(\mathbf{1 0 0 \% )}\end{array}$ & $42(57 \%)$ & $20(28 \%)$ & $11(15 \%)$ \\
\hline $\begin{array}{l}\text { Total } \\
\mathbf{n}=\mathbf{2 1 2}(\mathbf{1 0 0 \% )}\end{array}$ & $93(44 \%)$ & $63(30 \%)$ & $56(26 \%)$ \\
\hline
\end{tabular}

Table III: Distribution of the patients who had treatment after colposcopy.

\begin{tabular}{|c|c|c|}
\hline & $\begin{array}{l}\text { Patients who } \\
\text { had advanced } \\
\text { treatment }\end{array}$ & $\begin{array}{c}\text { Patients who did } \\
\text { not have advanced } \\
\text { treatment }\end{array}$ \\
\hline \multirow{4}{*}{$\begin{array}{l}\text { LSIL } \\
n=63(100 \%)\end{array}$} & LEEP: 7 & \\
\hline & Conization: 2 & \\
\hline & TAH: 1 & \\
\hline & Total: $10(16 \%)$ & $n=53(84 \%)$ \\
\hline \multirow{3}{*}{$\begin{array}{l}\text { HSIL } \\
n=56(100 \%)\end{array}$} & LEEP: 5 & \\
\hline & Conization: 26 & \\
\hline & Total: $31(55 \%)$ & $n=25(45 \%)$ \\
\hline
\end{tabular}

treatment (LEEP, conization or hysterectomy). Two patients with LSIL had conization, 7 patients with LSIL had LEEP and 1 patient with LSIL underwent hysterectomy while 26 of 31 patients with a diagnosis of HSIL had conization and 5 had LEEP (Table III).

\section{DISCUSSION}

HPV DNA testing in cervical cancer screening is now the first line screening test recommended by the European Union, the International Agency for Research On Cancer (IARC) and the World Health Organization (WHO) $(16,17)$. Although the sample collection methods are similar for both HPV DNA and cytology based screening programs, more patients can be screened by HPV DNA screening as screening with HPV DNA test requires less labor force and organization.

The number of women screened with HPV DNA screening in Turkey has been more than 5-6 times the number screened with cytology-based screening programs $(14,18)$. In Turkey, the Ministry of Health set national standards for a community-based cervical cancer screening program in 2014. The aim of this program was to screen the women between 30 and 65 years of age in the community every 5 years. It was predicted that $20 \%$ of the target population would be screened every year according to this program.

Between 2016 and 2017, a total of 23,010 women were screened in Çorum province, accounting for $48.3 \%$ of the total target population. According to age groups, the highest screening rate was in the age range of 50-59 years (59\%), and the lowest screening rate was in the age range of 30-39 (38\%) years. In a study by Gültekin et al. which included the screening results of 1 million women all over Turkey, it was stated that the highest screening rate was in the 40-44 years age range, the lowest was in the 60-65 years age range and the second lowest was in the 30-34 years age range (18). In our study, it was determined that there were difficulties in reaching the young female population in Çorum province.

Of the screened population. 817 (3.5\%) patients were positive for HPV DNA in Çorum. This ratio was found to be $3.5 \%$ in the study by Gultekin et al. (18). Kulhan et al. found that ratio was $2.79 \%$ in their study conducted in Erzincan province (19). Our positivity rate was largely similar to the screening results found in other parts of Turkey. In our study, $26.4 \%$ of all HPV DNA positive cases were detected as HPV type $16,4 \%$ as HPV type 18 , and $69.6 \%$ as other types of HPV. In the study by Gultekin et al., this ratio was 20.7\% for HPV 16, and 5.1\% for HPV 18 (18). Kulhan et al. found $11.25 \%$ HPV 16 and $2.27 \%$ HPV 18 positivity 
in their study (19). The most common type in Çorum was HPV 16 and compatible with the findings in other regions.

In our study, the group with the highest rate of HPV DNA positivity was the $30-39$ age group (4.2\%). This was followed by $40-49,50-59$ and $60-65$ years of age, respectively (Table I). Gultekin et al. and Kulhan et al. found that the HPV DNA incidence was the highest in the 30-39 years age group (18-19). HPV positivity decreases with age and goes down to $2.9 \%$ in the age range of $60-65$ years.

According to national guidelines, patients who are positive for HPV 16 and 18 should be directly referred to colposcopy. However, the patients who are positive for 'HPV other than 16 or 18 ' should be referred to colposcopy in case of squamous cell anomaly in cervicovaginal smear taken at the time of HPV DNA sampling. Colposcopic biopsy was performed in $212(26 \%)$ out of 817 women with HPV positivity in our hospital (Table II). When HPV type 16 and 18 were evaluated together, 109 of 248 patients (44\%) did not undergo colposcopy, which was required according to national guidelines. Gultekin et al. also stated that approximately $40.1 \%$ of women in the whole country were not followed according to the appropriate procedure, similar to our study (18). In that study, it was found that the pathological evaluation results of 1985 (56\%) of the 3499 patients who underwent colposcopic biopsy were normal, 708 (20\%) were LSIL, 721 (20\%) were HSIL and 85 (2.5\%) were invasive cancer (18). In our study, it was revealed that, $44 \%$ of the cases had non-SIL, $30 \%$ had LSIL and $26 \%$ had HSIL according to colposcopic biopsy results. In our study, the HSIL and LSIL rates were significantly higher than that of the results of Gultekin et al. The reason for this difference may be that the young population between the ages of 30 and 39 could not be screened sufficiently. If this age group could be screened adequately, the number of cases with HPV positivity and the correlation with the histomorphological lesions (LSIL/HSIL) could be established more reliably. However, the patient group who could not be further examined could also adversely affect the rates. Furthermore, no invasive tumor was detected as the result of colposcopic biopsies in our hospital. This may be due to the fact that patients who were suspected of invasive tumor during colposcopy might have been referred to advanced centers without taking a biopsy.

According to the national guideline, treatment (LEEP / Conization / Hysterectomy) should be performed especially for patients with HSIL. According to our results, 31 of the 56 (55\%) patients with HSIL underwent one of these procedures but no hospital records were found for the remaining $45 \%$ of the patients. Although some of these patients might have gone to advanced centers for treatment, some of the patients were thought to have remained untreated for reasons such as being unaware, too many patients, and not being able to make an appointment.

The percentage of women who were reached within the scope of national cancer screening program in Çorum province over two years shows similarities with the results all over Turkey. However, it is noteworthy that the percentage of the reached people was the lowest in the 3039 years age group, in which HPV DNA was expected to be most common, as in seen throughout Turkey. It is obvious that special programs and methods should be developed to reach this age group within the scope of screening. It was determined that $44 \%$ of HPV DNA-positive patients were not subjected to the appropriate processes according to national guidelines. The data were collected from a single center which was the only one where colposcopy was performed in Çorum province. It is possible that, a small number of these patients received their treatments in hospitals outside the province. However, when the sociocultural and economic aspects of Çorum are evaluated, this ratio will be very low and it is thought that a significant portion of this $44 \%$ section may not have received the appropriate treatment. It was also found that $45 \%$ of the patients with HSIL, who were the main target of all these screening programs and who were also at risk for developing invasive cancer, did not receive the necessary treatment. This shows that despite the screening, the desired therapeutic effect could not be achieved. This patient group needs to be directed to institutions performing colposcopy and to be followed by the institutions in order to ensure the necessary treatment after colposcopy.

\section{CONFLICT of INTEREST}

The authors declare no conflict of interest.

\section{REFERENCES}

1. Ferlay J, Shin HR, Bray F, Forman D, Mathers C, Parkin DM. Estimates of worldwide burden of cancer in 2008: GLOBOCAN 2008. Int J Cancer. 2010;127:2893-917.

2. Wardak S. Human Papillomavirus (HPV) and cervical cancer. Med Dosw Mikrobiol. 2016;68:73-84.

3. Zhang L, Bi Q, Deng H, Xu J, Chen J, Zhang M, Mu X. Human papillomavirus infections among women with cervical lesions and cervical cancer in Eastern China: Genotype-specific prevalence and attribution. BMC Infect Dis. 2017;17:107.

4. Sasaki Y, Iwanari O, Arakawa I, Moriya T, Mikami Y, Iihara K, Konno R. Cervical cancer screening with human papillomavirus DNA and cytology in Japan. Int J Gynecol Cancer. 2017;27: 523-9. 
5. Fernandez AF, Rosales C, Lopez-Nieva P, Graña O, Ballestar E, Ropero S, Espada J, Melo SA, Lujambio A, Fraga MF,Pino I, Javierre B, Carmona FJ, Acquadro F, Steenbergen RD, Snijders PJ, Meijer CJ, Pineau P, Dejean A, Lloveras B, Capella G, Quer J, Buti M, Esteban JI, Allende H, Rodriguez-Frias F, Castellsague X, Minarovits J, Ponce J, Capello D, Gaidano G, Cigudosa JC, Gomez-Lopez G, Pisano DG, Valencia A, Piris MA, Bosch FX, Cahir-McFarland E, Kieff E, Esteller M. The dynamic DNA methylomes of double-stranded DNA viruses associated with human cancer. Genome Res. 2009;19:438-51.

6. Ghosh S, Seth, Paul J, Rahman R, Chattopathyay S, Bhadra D. Evaluation of Pap smear, high risk HPV DNA testing in detection of cervical neoplasia with colposcopy guided or conventional biopsy as gold standard. Int J Healthcare Biomed Res. 2014;2: 192-7.

7. Walboomers JM, Jacobs MV, Manos MM, Bosch FX, Kummer JA, Shah KV, Snijders PJ, Peto J, Meijer CJ, Muñoz N. Human papillomavirus is a necessary cause of invasive cervical cancer worldwide. J Pathol. 1999;189:12-9.

8. Harper DM, DeMars LR. HPV vaccines - a review of the first decade. Gynecol Oncol. 2017;146:196-204.

9. Catarino R, Petignat P, Dongui G, Vassilakos P. Cervical cancer screening in developing countries at a crossroad: Emerging technologies and policy choices. World J Clin Oncol. 2015;6: 281-90.

10. Ferlay J, Soerjomataram I, Dikshit R, Eser S, Mathers C, Rebelo M, Parkin DM, Forman D, Bray F. Cancer incidence and mortality worldwide: Sources, methods and major patterns in GLOBOCAN 2012. Int J Cancer. 2015;136:E359-86.

11. Açikgöz A, Ergör G. Cervical cancer risk levels in Turkey and compliance to the national cervical cancer screening standard. Asian Pac J Cancer Prev. 2011;12:923-7.
12. Sevil S, Kevser O, Aleattin U, Özlem D. The frequency of having pap-smear tests among women between 15-64 years old and the evaluation of the level of their knowledge. J Pak Med Assoc. 2013;63:873-7.

13. Daloglu FT, Karakaya YA, Balta H, Eren A,Aslihan D. Cervical cytological screening results of 8,495 cases in Turkey-common inflammation but infrequent epithelial cell abnormalities? Asian Pac J Cancer Prev. 2014;15:5127-31.

14. Mehmetoglu HC, Sadikoglu G, Ozcakir A, Bilgel N. Pap smear screening in the primary health care setting: A study from Turkey. N Am J Med Sci. 2010;2:467-72.

15. Demirhindi H, Nazlican E, Akbaba M. Cervical cancer screening in Turkey: A community-based experience after 60 years of pap smear usage. Asian Pac J Cancer Prev. 2012;13:6497-500.

16. European Guidelines for Quality Assurance in Cervical Cancer Screening. 2nd ed. Supplements. Anttila A, Arbyn M, Vuyst de H, Dillner J, Dillner L, Franceschi S, Patnick J, Ronco G, Segnan N, Suonio E, Törnberg S, von Karsa L, editors. Luxembourg: European Union Publications; 2015. 194.

17. Huh WK, Ault KA, Chelmow D, Davey DD, Goulart RA, Garcia FA, Kinney WK, Massad LS, Mayeaux EJ, Saslow D, Schiffman M, Wentzensen N, Lawson HW, Einstein MH. Use of primary highrisk human papillomavirus testing for cervical cancer screening: Interim clinical guidance. Gynecol Oncol. 2015;136:178-82.

18. Gultekin M, Zayifoglu Karaca M, Kucukyildiz I, Dundar S, Boztas G, Semra Turan H, Hacikamiloglu E, Murtuza K, Keskinkilic $B$, Sencan I. Initial results of population based cervical cancer screening program using HPV testing in one million Turkish women. Int J Cancer. 2018;142:1952-8.

19. Kulhan M, Kulhan NG, Seven Y, Nayki UA, Nayki C, Ata N, Ulug P. Estimation of the prevalence and distribution of HPV genotypes and identification of related risk factors among Turkish women. Contemp Oncol (Pozn). 2017;21:218-23. 